\title{
Organoleptic Evaluation and Profitability Analysis of "Yoghurt-Like Product" Manufactured using Tiger Nut
}

\author{
Agwuna, Linus Chukwuma, Okonkwo, Ifeyinwa Felicia, Egbuim, Timothy Chukwudiegwu
}

\author{
Department of Applied Microbiology and Brewing, Faculty of Biosciences, \\ Nnamdi Azikiwe University, Awka, Anambra, Nigeria
}

How to cite this paper: Agwuna, Linus
Chukwuma | Okonkwo, Ifeyinwa Felicia
I Egbuim, Timothy Chukwudiegwu
"Organoleptic Evaluation and
Profitability Analysis of "Yoghurt-Like
Product" Manufactured using Tiger Nut"
Published in International Journal of
Trend in Scientific Research and
Development (ijtsrd), ISSN: 2456-6470,
Volume-3 | Issue-4,
June 2019, pp.315-
318, URL:
https://www.ijtsrd.c
om/papers/ijtsrd23
573.pdf

Copyright (C) 2019 by

author(s) and International Journal of Trend in Scientific Research and Development Journal. This is an Open Access article distributed under the terms of the Creative Commons Attribution License

(CC BY 4.0)

(http://creativeco

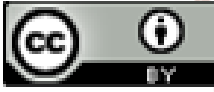

mmons.org/licenses/by/4.0)
ABSTRACT

In this study, tiger nut milk was produced using a standard method and employed in yoghurt production. The following investigations were carried out on the tiger nut yoghurt produced; microbial analysis by plate count method, organoleptic evaluation using 9 point Hedonic scale and profitability analysis by cost per unit volume. The result of total plate counts were $3.5 \times 10^{1} \mathrm{cfu} / \mathrm{ml}, 4.2 \times$ $10^{1} \mathrm{cfu} / \mathrm{ml}, 3.7 \times 10^{1} \mathrm{cfu} / \mathrm{ml}$ and $4.4 \times 10^{1} \mathrm{cfu} / \mathrm{ml}$ for produced tiger nut yoghurt, Market yoghurt 1, Market yoghurt 2 and Market yoghurt 3, respectively. The result of yeast and mould counts were $3.7 \times 10^{1} \mathrm{cfu} / \mathrm{ml}, 4.3 \times 10^{1} \mathrm{cfu} / \mathrm{ml}, 3.8 \times$ $10^{1} \mathrm{cfu} / \mathrm{ml}$ and $4.4 \times 10^{1} \mathrm{cfu} / \mathrm{ml}$ for produced tiger nut yoghurt, Market yoghurt 1, Market yoghurt 2 and Market yoghurt 3, respectively. The coliform count showed no growth for all the samples. The results of the mean rating by the panellists for tiger nut yoghurt were $7.53,6.80,6.20,7.80$ and 7.50 for colour, taste, smell, mouth-feel and overall acceptability, respectively while the panellists mean rating for commercial yoghurts were 8.05, 6.72, 7.00, 7.40, 7.31 for colour, taste, smell, mouth-feel and overall acceptability, respectively. The economic analysis of the study revealed that it costs only $\mathbf{N} 185$ to produce $500 \mathrm{ml}$ of tiger nut yoghurt while commercial yoghurt of the same volume costs $\mathbf{2} 215$ on the average.

KEYWORDS: Yoghurt, Tiger nut, Organoleptic, Profitability Analysis

1. INTRODUCTION

Yoghurt is a coagulated milk product that results from the fermentation of lactic acid in milk by Streptococcus thermophilus and Lactobacillus delbrueckii subsp. bulgaricus (Bataway and Khalil, 2018). Fermentation of lactose by these bacteria produces lactic acid, which acts on milk protein to give yoghurt its textures and characteristics tang (Sanful, 2009).
Yoghurts come in a variety of textures (liquid, set and stirred curd), fat contents (regular fat, low-fat and fat-free) and flavors (natural, fruit, cereal, chocolate), and can be consumed as a snack, part of a meal, as sweet or savory food (Reeta et al., 2015). The versatility, together with their acceptance as healthy and nutritious food, has led to their widespread popularity across all populations (Mckinley, 2005).

Vegetable milk is a product of plant origin which presents aspects close to the milk of animal origin (Malik et al., 2012). It has been consumed for centuries in various cultures, both as a regular drink (such as the Spanish horchata) and as a substitute for dairy milk. The most popular varieties are soymilk, almond milk, rice milk, coconut milk and tiger nut milk (Ukwuru and Ogbodo, 2011; Sethi et al., 2016). The protein content varies, it contains no lactose or cholesterol and is usually sold with added calcium and vitamins especially B12. According to Sethi et al. (2016), there are several reasons for choosing cow milk alternatives which include; cow milk allergy, lactose intolerance, veganism, calorie concern and prevalence of hypercholesterolemia. Plant milk is used to make plant cream, ice-cream, vegan cheese and yoghurt such as tiger nut yoghurt and soy yoghurt).
Tiger nuts are sweet nut-like vegetable root tubers of the perennial grass-like cyperaceous plant called Cyperus esculentus L. (Coskuner et al., 2002). The plant thrives in the tropical and Mediterranean regions; it's commonly grown in Nigeria, Ghana, Togo, Ivory Coast, Spain and Egypt where the root tubers are mainly used as a source of food nutrients (Pascual et al., 2000). Tiger nuts are rich in carbohydrate, lipids, fibre, some proteins, minerals, ascorbic acids and $\alpha$ tocopherols (Ekeanyanwu and Ononogbu, 2010). To exploit their nutritional potentials, tiger nuts have recently been experimented for enriching the fibre content in gluten-free bread and biscuits (Aguilar et al., 2015; Zahra and Ahmed, 2014). Lactic acid fermentation of tiger nut milk is of particular interest because of the prospects to generate lactose-free, yoghurt-like products of improved microbial stability and extended shelf life with acceptable sensory properties. Such fermented systems might be promising as a valuable alternative source of food nutrients, especially in many developing countries where the population present a high prevalence of lactose intolerance and limited access to nutritious food (Vesa et al., 2000).

The continued diary milk shortage or absence in developing countries has led to the production of milk substitutes from vegetables. According to Harkins and Sarret (1967), the 
development of milk substitutes extracted from cereals and legumes serve as an alternative way of producing acceptable nutritious food based on vegetables. Although yoghurts are produced in Nigeria, the need for cost-effective major raw material for yoghurt production as well as lactose-free yoghurt-like products cannot be overemphasized. The high cost of cow milk has led to explorations on local substrates that will serve as major raw material for yoghurt production. Considering the economic situation of the country, there is a need for the adoption of local and cheap materials for products that are cheaper and readily available for general consumption.

\section{MATERIALS AND METHODS}

\section{Sample Collection}

Tiger nut for milk production was purchased from Eke-Awka market in Awka, Anambra State.

Starter cultures Streptococcus thermophilus and Lactobacillus bulgaricus were purchased from Onitsha main market, Anambra State.

\section{Equipment and Reagents}

Processing facilities which include homogenizer, water bath, Waring blender, refrigerator and other equipment, as well as reagents, were provided by the Department of Applied Microbiology and Brewing, Nnamdi Azikiwe University, Awka, Anambra State, Nigeria.

\section{Milk Extraction Method}

The extraction of milk (Figure 1) was carried out by the modification of the traditional method of milk extraction as described by Ofori-Anti (2000). One kilogram (1kg) of tiger nut was milled with $2000 \mathrm{ml}$ of distilled water in a Waring blender at high speed for 10 minutes. The milk slurry was pressed through cheesecloth; the milk obtained was fortified with $2 \mathrm{~g}$ of glucose and was used for yoghurt production.

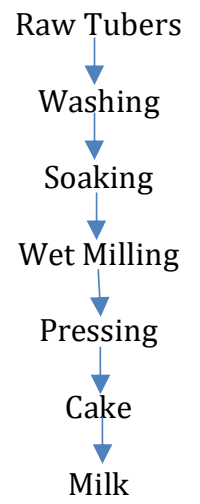

Figure: 1: Flow Diagram for milk production from tiger nut tubers (Ofori-Anti, 2000).

\section{Preparation of Yogurt}

The tiger nut milk was filtered of impurities using cheesecloth. The temperature of the milk was gradually increased to $80^{\circ} \mathrm{C}$ for $60 \mathrm{~min}$ to ensure proper pasteurization. Pasteurized tiger nut milk was rapidly cooled to $44^{\circ} \mathrm{C}$ for purpose of starter culture addition; $5 \mathrm{~g}$ of starter culture was added and stirred for $4 \mathrm{~min}$. Thereafter, sterilized bottle jar with a tight seal was filled with milk and incubated in a water bath at $44^{\circ} \mathrm{C}$ for $4 \mathrm{~h}$ until complete coagulation. Manufactured yoghurt was stored in a refrigerator at $5^{\circ} \mathrm{C}$ as described by Tamime and Robinson (1985).

\section{Microbiological Analysis}

Microbiological analysis was done on the tiger nut yoghurt produced and purchased yoghurt samples to give an indication of their microbial load. $5 \mathrm{ml}$ each of the produced and market yoghurts were homogenized for $1 \mathrm{~min}$ in an electromechanical homogenizer (Stomacher, Lab-blender 3500, Seward Medical, London, UK). Serial dilutions of the samples were prepared for plating. Plate Count Agar (PCA) was used for enumeration of total plate count and the plates were incubated at $37^{\circ} \mathrm{C}$ for $24 \mathrm{~h}$. Yeast Extract Agar (YEA) was used for yeast and mould enumeration; the plates were incubated at $25^{\circ} \mathrm{C}$ for 48 hours, according to Marshall (1992). Violet Red Bile Agar was used for the enumeration of coliforms and the plates were incubated at $37^{\circ} \mathrm{C}$ for $24 \mathrm{~h}$, according to Marshall (1992).

\section{Organoleptic Evaluation}

The overall acceptability of tiger nut yoghurt manufactured was carried out by 20 panellists according to the method described by Sameen et al. (2016). Appearance, colour, taste, smell, mouth-feel and general acceptability ranking were assessed for organoleptic evaluation; the mean of the manufactured yoghurt and of three popular market yoghurts was taken. The organoleptic evaluation was done using 9 point Hedonic scale. The ratings were as shown below:

Rating Acceptability

Like extremely

Like very much

Like moderately

Like slightly

Neither like nor dislike

Dislike slightly

Dislike moderately

Dislike very much

Dislike extremely

Profitability Analysis

Profitability analysis was carried out to ascertain the cost of producing a $500 \mathrm{ml}$ bottle of the yoghurt and those of some popular yoghurts of the same quantity in the market.

The cost of the following was found and recorded:

1. Tiger nut per kilogram

2. Flavour used (Vanilla) per $\mathrm{ml}$

3. Sucrose sugar per gram

4. Cost of water per 2 litres

5. Cost of other inputs used

The total unit cost of producing $500 \mathrm{ml}$ of yoghurt using tiger nut was compared to the mean cost of three commercial yoghurts popular in the market.

\section{RESULTS}

Microbial Counts of Yoghurt Products

Table 1: Aerobic Plate Count-Total Viable Count of the Finished Product and Market Yoghurts

\begin{tabular}{|c|c|}
\hline Samples & Count(s) $(\mathrm{Cfu} / \mathrm{ml})$ \\
\hline Produced tiger nut yoghurt & $3.5 \times 10^{1}$ \\
\hline Market yoghurt 1 & $4.2 \times 10^{1}$ \\
\hline Market yoghurt 2 & $3.7 \times 10^{1}$ \\
\hline Market yoghurt 3 & $4.4 \times 10^{1}$ \\
\hline
\end{tabular}


International Journal of Trend in Scientific Research and Development (IJTSRD) @ www.ijtsrd.com eISSN: 2456-6470

Table 2: Yeast and Mould Counts of the Finished Product and Market Yoghurts

\begin{tabular}{|c|c|}
\hline Samples & Count $(\mathrm{s})(\mathrm{Cfu} / \mathrm{ml})$ \\
\hline Produced tiger nut yoghurt & $3.7 \times 10^{1}$ \\
\hline Market yoghurt 1 & $4.3 \times 10^{1}$ \\
\hline Market yoghurt 2 & $3.8 \times 10^{1}$ \\
\hline Market yoghurt 3 & $4.4 \times 10^{1}$ \\
\hline
\end{tabular}

Table 3: Coliform Counts of the Finished Product and Market Yoghurt

\begin{tabular}{|c|c|}
\hline Samples & Count(s) $(\mathrm{Cfu} / \mathrm{ml})$ \\
\hline Produced tiger nut yoghurt & 0 \\
\hline Market yoghurt 1 & 0 \\
\hline Market yoghurt 2 & 0 \\
\hline Market yoghurt 3 & 0 \\
\hline
\end{tabular}

\section{Results of Organoleptic Analysis}

The panellists comprised of $40 \%$ women and $60 \%$ men, majorly postgraduate students and staff of Department of Applied Microbiology and Brewing, Nnamdi Azikiwe University, Awka. Majority of them reported that they consume yoghurt at least once in a month and just a few of them reported that they consume yoghurt at least once every week. The results of the organoleptic evaluation conducted were shown in Table 4 as mean scores \pm standard deviation.

Table 4: Organoleptic Evaluation of Tiger Nut Yoghurt Produced and Market Yoghurts

\begin{tabular}{|c|c|c|}
\hline $\begin{array}{c}\text { Organoleptic } \\
\text { Attributes }\end{array}$ & $\begin{array}{c}\text { Tiger Nut } \\
\text { Yoghurt }\end{array}$ & $\begin{array}{c}\text { Market Yoghurt } \\
(1,2 \text { and 3) }\end{array}$ \\
\hline Colour & $7.53^{\mathrm{b}} \pm 0.43$ & $8.05^{\mathrm{a}} \pm 0.34$ \\
\hline Taste & $6.80^{\mathrm{a}} \pm 0.23$ & $6.72^{\mathrm{a}} \pm 0.03$ \\
\hline Smell & $6.20^{\mathrm{b}} \pm 0.03$ & $7.00^{\mathrm{a}} \pm 0.01$ \\
\hline Mouth-feel & $7.80^{\mathrm{a}} \pm 0.41$ & $7.40^{\mathrm{a}} \pm 0.34$ \\
\hline Overall acceptability & $7.50^{\mathrm{a}} \pm 0.33$ & $7.31^{\mathrm{a}} \pm 0.32$ \\
\hline
\end{tabular}

Key:

1. Results are means of twenty organoleptic scores \pm Standard deviation

2. Means in the same column with the same superscript are not significantly different $(p>0.05)$

\section{Profitability Analysis}

Table 5 represents the total cost of raw materials purchased for tiger nut yoghurt production and their unit price per gram; this was to deduce the quantity and price of the raw materials involved in producing $500 \mathrm{ml}$ of yoghurt.

Table 5: Prices of Materials for Yoghurt Production

\begin{tabular}{|c|c|c|c|c|c|}
\hline $\mathbf{S} / \mathbf{N}$ & Material & Quantity & $\begin{array}{l}\text { Total Cost } \\
\text { for } 2 \text { litres }\end{array}$ & \begin{tabular}{|c|} 
Unit \\
price $/ 500 \mathrm{ml}$ \\
\end{tabular} & $\begin{array}{l}\text { Mean price of } 3 \\
\text { market yoghurts }\end{array}$ \\
\hline 1 & Tiger nut & $1 \mathrm{~kg}$ & N300 & N75 & \\
\hline 2 & Starter culture (yogourmet) & One packet(5g) & Durn $\mathbf{N} 300$ & $\mathbf{N} 75$ & \\
\hline 3 & Sugar & $2 \mathrm{~g}$ & N20 & N5 & \\
\hline 4 & Flavour (vanilla) & $5 \mathrm{ml}$ & N20 & O & \\
\hline 5 & Water & 2 litres & N20 & N5 & \\
\hline 6 & Packaging container & 4 bottles $(500 \mathrm{ml} \mathrm{each})$ & N80 & $\begin{array}{l}\mathbf{N} 20 \\
\end{array}$ & \\
\hline & The total amount per $500 \mathrm{ml}$ & . & $8<$ & $\mathbf{N 1 8 5}$ & N215 \\
\hline
\end{tabular}

\section{Discussion}

Aerobic plate count is used as an indicator of bacterial populations in a food sample (Belewu and Abodunrin, 2006). The population of bacteria in the yoghurt samples ranged from $3.5 \times 10^{1}$ to $4.4 \times 10^{1}$. Garbutt (1997) stated that microbial count less than 30 colonies or less than $2.4 \times 10^{4}$ colony forming units per $\mathrm{ml}$ for the viable bacterial count in a mixed culture is negligible or insignificant in food quality and safety assessment, thus, the tiger nut yoghurts were suitable for human consumption. The yeast and mould counts for the samples did not exceed the microbiological counts of $1.0 \times 10^{4} \mathrm{cfu} / \mathrm{ml}$ (Table 2) indicating that they were safe for consumption. No coliforms were detected in the samples, which is in accordance with the microbiological standards (Table 3). This indicates that the samples were within acceptable limit hence safe for consumption.

The organoleptic scores for tiger nut yoghurt produced in comparison with commercial yoghurts in the market were shown in Table 4; all the panellists rated the product considerably high in almost all the attributes evaluated. The result showed that the colour of the produced tiger nut yoghurt recorded high mean score of 7.53 which translates to "like moderately" on the 9-point hedonic scale while commercial yoghurt recorded a mean score of 8.05 which translates to "like very much" on the same scale. The colour was based on how the appearance appealed to the panellists.
There was a significant difference between the tiger nut yoghurt and commercial yoghurt based on colour $(\mathrm{p}<0.05)$. The rating for Taste followed almost the same trend as it has a mean rating score of 6.80 while commercial yoghurt recorded 6.72 which translates to "like moderately". The results showed that tiger nut yoghurt can give a good taste of yoghurts. There was no significant difference between the tiger nut yoghurt and commercial yoghurt based on taste $(p>0.05)$. The smell of the tiger nut yoghurt was also accepted by the panellists as it recorded reasonable high mean score of 6.20 which translates to "like slightly", although the commercial yoghurt recorded a higher mean score of 7.0 which translate to "like moderately". There was a significant difference between the tiger nut yoghurt and commercial yoghurt based on smell $(\mathrm{p}<0.05)$.

The score for mouth-feel recorded a high score of 7.80 which translates to "like very much" compared to commercial yoghurt that recorded a mean score of 7.40 which translates to "like moderately" on the 9-point hedonic scale. There was no significant difference between the tiger nut yoghurt and commercial yoghurt based on mouth-feel ( $p>0.05)$. On the general acceptability, tiger nut yoghurt was most preferred as it had the highest mean score of 7.50 translating to "like very much" while the commercial yoghurt had the mean score of 7.31 translating to "like moderately". Many of the panellists after the evaluation declared interest to buy the product if brought to the market. Results of the profitability 
analysis showed that it costs only $\mathbf{N} 185$ to produce $500 \mathrm{ml}$ of tiger nut yoghurt while commercial yoghurt of the same volume cost $\mathbf{N} 215$ on average. The results of the study showed that tiger nut yoghurts are more economical to produce in comparison to commercial yoghurts produced using cow milk.

\section{CONCLUSION}

Based on the findings of this work, it is concluded that yoghurt production from tiger nut milk is feasible and could be most appreciated by low-income earners and lactose intolerant patients. Also, the product is safe for human consumption and can compete favourably with commercial yoghurts in terms of organoleptic evaluation and cost.

\section{REFERENCES}

[1] Aguilar, N., Albanell, E., Minarro, B., Guamis, B. and Capellas, M. (2015). Effect of tiger nut-derived products in gluten-free batter and bread. Food Science and Technology International, 21: 323-331.

[2] Batawy, O. and Khalil, O. (2018). Manufacture and properties of low-fat bio yoghurt containing probiotic strains and maltodextrin as prebiotic. Journal of Probiotics and Health, 6(1): 1-9.

[3] Belewu, M. A. and Abodunrin, O. A. (2006). Preparation of kunnu from unexploited rich food source: Tiger nut (Cyperus esculentus). World Journal of Dairy and Food Sciences, 1(1): 19-21.

[4] Coskuner, Y., Ercan, R., Karababa, E. and Nazlican, A.N.(2002). Physical and chemical properties of chufa (Cyperus esculentus L) tubers grown in the Çukurova region of Turkey. Journal of the Science of Food and Agriculture, 82: 625-631.

[5] Ekeanyanwu, R.C. andOnonogbu, C.I.(2010). Nutritive value of Nigerian tiger nut (Cyperus esculentus L.). Medwell Journals of Agriculture, 5: 297-302.

[6] Garbutt, J. (1997). Essentials of food microbiology. London: Arnold Publishers. Pp. 103-245.

[7] Harkins, R.W. and Sarret, H. P. (1967). Methods of comparing protein quality of soybean infant formulas in rat. Journal of Nutrition, 91: 213-216.

[8] Malik, A. H., Anjum, F.M., Sameen, A., Khan, M.I. and Sohaib, M. (2012). Extraction of starch from water chestnut (TrapabispinosaRoxb) and its application in yoghurt as a stabilizer. Pakistan Journal of Food Science, 22: 209-218.
[9] Marshall, T. R. (1992). Standard method for the examination of dairy product (16th ed). American Public Health Association, Washington, D. C.

[10] Mckinley, M.C. (2005). The nutrition and health benefits of yoghurt. International Journal of Dairy Technology, 58 (1): 1-12.

[11] Ofori-Anti, A.O.(2000). Tiger nuts (Cyperus Esculentus): production processing and product development. issertation submitted to the Department of Nutrition and Food Science, University of Ghana.

[12] Pascual, B., Maroto, J.V., LóPez-Galarza, Sa., Sanbautista, A. and Alagarda, J.(2000). Chufa (Cyperus esculentus L. var. sativus boeck.): An unconventional crop. Studies related to applications and cultivation. Economic Botany, 54: 439-448.

[13] Reeta, K. S., Ankita, J.and Ramadevi, N. (2015). Fortification of yoghurt with health- promoting additives: a review. Research and Reviews: Journal of Food and Dairy Technology, 3(3): 9-17.

[14] Sameen, A., Sattar, M.U., Javid, A., Ayub, A. and Khan, M.I. (2016). Quality evaluation of yoghurtstabilized with sweet potato (Ipomoea batatas) and taro (Colocasia esculenta) starch. International Journal of Food and Allied Science, 2: 23-29.

[15] Sanful, R. E. (2009). The use of tiger-nut (Cyperus esculentus), cow milk and their composite as substrates for yoghurt production. Pakistan Journal of Nutrition, 8: 755-758.

[16] Sethi, S., Tyagi, S. K. and Anurag, R. K. (2016). Plantbased milk alternatives an emerging segment of functional beverages: A review. Journal of Food Science and Technology, 53(9): 3408-3423.

[17] Tamime, A. Y. and Robinson, R.K. (1985). Yoghurt science and technology. Oxford: Pergamon Press.

[18] Ukwuru, M.U. and Ogbodo, A.C.(2011). Effect of processing treatment on the quality of tigernut milk. Pakistan Journal of Nutrition, 10: 95-100.

[19] Vesa, T.H., Marteau, P. and Korpela, R.(2000). Lactose intolerance. Journal of the American College of Nutrition, 19: 165-175.

[20] Zahra, S. and Ahmed, M.S.H.(2014). Exploring the suitability of incorporating tiger nut flour as novel ingredient in gluten-free biscuit. Polish Journal of Food and Nutrition Sciences, 64: 27-33. 